Международная Объединенная Академия Наук

\title{
Научные тенденции: Юриспруденция
}

Сборник научных трудов

по материалам

XXIII международной научной конференции

20 августа 2020 г.

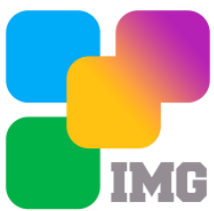

Санкт-Петербург 2020 
УДК 001.1

ББК 60

Научный диалог: Юриспруденция. Сборник научных трудов по материалам XXIII международной научно-практической конференции 20 августа 2020 г. Изд. ЦНК МОАН, 2020. - 32 с.

\section{SPLN 001-000001-0686-JP \\ DOI 10.18411/spc-20-08-2020 \\ IDSP sciencepublic-20-08-2020}

В сборнике научных трудов собраны материалы из различных областей научных знаний. В данном издании приведены все материалы, которые были присланы на XXIII международную научно-практическую конференцию Научный диалог: Юриспруденция

Сборник предназначен для научных работников, преподавателей, аспирантов и студентов.

Все материалы, размещенные в сборнике, опубликованы в авторском варианте. Редакция не вносила коррективы в научные статьи. Ответственность за информацию, размещенную в материалах на всеобщее обозрение, несут их авторы.

Информация об опубликованных статьях будет передана в систему Российского индекса научного цитирования (РИНЦ) и наукометрическую базу SPINDEX

Электронная версия сборника доступна на сайте ЦНК MOAН. Сайт центра: conf.sciencepublic.ru

УДК 001.1

ББК 60 


\section{Соgержсание}

РАЗДЕЛ I. ГОСУДАРСТВЕННОЕ, КОНСТИТУЦИОННОЕ,

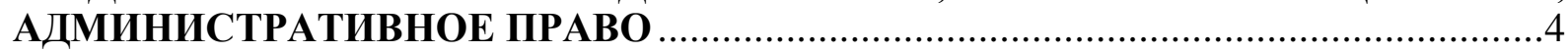

Баканова О.Д. Обеспечение прав человека в деятельности прокуратуры России...........4

РАЗДЕЛ ПІ. ПРАВО. ОБЩИЕ ВОПРОСЫ .9

Кабакова А.О. Судьба стадии возбуждения уголовного дела ...................................9

Смирнов О.В. Юридический процесс и процедура: понятие, сущность, различия .......11

Трубицына Д.С. Адвокатура и адвокатская деятельность в Российской Федерации:

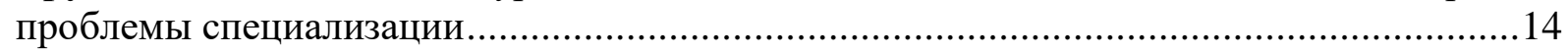

Цвик Е.Б., Ярощук И.А. Специфика молодёжного экстремизма в России ...................16

РАЗДЕЛ ІІІ. ГРАЖДАНСКОЕ ПРАВО

Авдеева Н.И. Признание и исполнение решений иностранных судов о взыскании алиментов на территории Российской Федерации.

Пожидаева А.С. Конфискация орудия совершения или предмета административного правонарушения как вид административного наказания за правонарушение в сфере предпринимательской деятельности

РАЗДЕЛ IV. МЕЖДУНАРОДНОЕ ПРАВО 26

Чертова Н.А., Жура С.Е., Тетерин А.В. Правовые аспекты регулирования международного научно-технического сотрудничества в сфере комплексного изучения Арктики..... .26

РАЗДЕЛ У. УГОЛОВНОЕ ПРАВО .28

Агафонов В.В. Анализ положений соборного уложения 1649 года о правомерном причинении вреда при задержании лица, совершившего преступление 28 


\title{
РАЗДЕЛ І. ГОСУДАРСТВЕННОЕ, КОНСТИТУЦИОННОЕ, АДМИНИСТРАТИВНОЕ ПРАВО
}

\author{
Баканова О.Д. \\ Обеспечение прав человека в деятельности прокуратуры России \\ ФГКОУ ВО «Университет прокуратуры Российской Федераџии»
}

(Россия, Москва)

doi:10.18411/spc-20-08-2020-01

idsp: sciencepublic-20-08-2020-01

\section{Аннотация}

Перед Россией проблема обеспечения прав человека стоит как никогда остро. Во-первых, одни просто не знают о существовании у себя каких-либо прав, другие знают, что у них есть права, но что они из себя представляют, понимают не до конца, третьи просто не знают, куда обратиться, когда их права были нарушены. Эти права имеют естественную природу и неотчуждаемы от человека, они не ограничиваются ни территориальными, ни национальными рамками, характеризуют человека как представителя рода человеческого. Каждый человек наделен данными правами просто потому, что он человек. В рамках, определенных законом, права человека неотъемлемы и принадлежат всем людям в равной степени независимо от их национальности, социального статуса, вероисповедания и тому подобное. Государство должно не только не нарушать прав человека в своей деятельности, но и защищать права одних людей от посягательств со стороны других. Кроме того, права человека должны быть защищены законом. Учитывая значимость прав человека в обеспечении нормальной жизнедеятельности общества, следует обратить особое внимание на механизмы и процедуры их защиты и реализации, показать особенности правоохранных механизмов и то какую они играют роль.

Ключевые слова: право, права человека, обеспечение прав, надзор, надзорные органы, прокуратура

\section{Abstract}

Before Russia the problem of human rights is more than ever. First, some simply do not know about the existence of any of the rights, others know they have rights, but what they are, you don't completely understand, others just don't know where to turn when their rights have been violated. These rights are natural and inalienable from the person, they are not limited to territorial, national framework, characterize man as a member of the human race. Each person has these rights simply because he is a man. In accordance with the law, human rights are inalienable and belong to all people equally regardless of their nationality, social status, religion and the like. The state should not only not violate human rights in their activities, but also to protect the rights of some people from encroachment by others. In addition, human rights should be protected by law. Given the importance of human rights in ensuring the normal functioning of society, should pay particular attention to the mechanisms and procedures for their protection and implementation, to show the features of enforcement mechanisms and what role they play.

Keywords: law, human rights, empowerment, supervision, Supervisory authorities, prosecutors.

Что бы наиболее полно выявить проблемы обеспечения прав человека, необходимо определить, что же такое права человека? Понятие права человека рассматривается многими как отечественными исследователями, так и иностранными 
учеными. Кроме того, понятие прав человека закреплено в международных нормативно-правовых актах. В.С. Нерсесянц писал: «Право вообще и права человека это необходимый, неотъемлемый и неизбежный компонент всякого права как права вообще, определенный (а именно - субъектно-человеческий) аспект выражения сущности права как особого типа и специфической формы социальной регуляции. Право без прав человека также невозможно, как и права человека без и вне права» [1]. Вот как определил права человека Т.Н. Радько: «Права человека - это социальные и юридические возможности пользоваться материальными, социальными и иными благами». Н.А. Баранов тоже не оставил без внимания эту тему, он понимает права человека, как охраняемую законом меру возможного поведения, направленную на удовлетворение интересов человека. Права человека - универсальная категория, представляющая собой вытекающие из самой природы человека возможности пользоваться элементарными, наиболее важными благами и условиями безопасного, свободного существования личности в обществе. В современный период права человека понимаются как общесоциальное понятие, отражающее наднациональные, общечеловеческие требования и стандарты в области свободы личности [3].

Согласно Всеобщей Декларации прав человека каждый человек должен обладать всеми правами и всеми свободами, провозглашенными настоящей Декларацией, без какого бы то ни было различия, как-то: в отношении расы, цвета кожи, пола, языка, религии, политических или иных убеждений, национального или социального происхождения, имущественного, сословного или иного положения. В Конституции нашей страны во второй главе закреплены основные права и свободы человека и гражданина. В статье 17 сказано, что в РФ признаются и гарантируются права и свободы человека и гражданина. Эти права неотчуждаемы и принадлежат каждому от рождения.

Теперь, когда мы рассмотрели мнения разных ученых, нормативные акты, мы можем сформулировать свое определение правам человека. Права человека - это совокупность прав, появляющихся у человека с рождения независимо от его национальности, расы, пола, возраста, убеждений и вероисповедания и охраняемые государством. Они представляют собой возможность пользоваться благами для удовлетворения интересов человека.

Надо сказать, что институт прав человека появился достаточно давно. Формирование теории существования прав человека относят к эпохе Нового времени, к XVII-XVIII веку. Но сами идеи о существовании таких прав появились еще в Древнем мире, когда государство только зарождалось. Правовая теория того времени строилась на том, какое положение занимает личность в государстве. Само, собой, что понятие прав человека не существовало. И основная ценность полиса - это коллективная свобод, то есть свобода как гражданина полиса. Постепенно появляются идеи прав человека в V-IV вв. до н. э., а именно, в Афинском полисе.

Права человека характеризуются определенными признаками, о которых необходимо сказать:

1. Всеобщность - это значит, что права человека универсальны. Принадлежат всем от рождения, в любом государстве, несмотря на то, какой бы государственное устройство, политический режим, какая идеология у этого государства не была. А также они реализуются, где бы не находился человек.

2. Равенство - так же этот принцип достаточно часто называют принципом не дискриминации. То есть, это говорит о том, что, права человека принадлежат всем людям независимо от расы, национальности, вероисповедания, убеждений, социального статуса, принадлежности к организациям. Все люди равны по отношению друг к другу.

3. Неотъемлемость - человека нельзя лишить этих прав. Никто не вправе отобрать эти права у него. Даже сам человек не может отказаться от этих прав. Лишь в 
исключительном случае, по решению суда человека могут лишить прав. Например, ограничить свободу передвижения, если он виновен в совершении преступления.

4. Неделимость - смысл этого принципа заключается в том, что все группы прав: политические, личные, экономические, социальные, культурные связаны. Нарушения одних прав как следствие влечет нарушение других.

5. Непосредственно действующие - это означает, что независимо от того, существуют ли законодательные акты или нет государственные органы, должностные лица должны их соблюдать.

Права человека также можно разделить на составляющие в аспекте взаимоотношений государство - личность, которые образуют правовой статус личности:

- Статус - негативус - сфера отношений, в которую о не вправе вмешиваться государство и частные лица. Это личные права человека, а также социальные, экономические и культурные.

- Статус - активус - сфера участия в управлении делами государства. Это избирательные права граждан, право на свободное выражении своего мнения.

- Статус - позитивус - сфера, требующая совершения от государства определенных действий или оказания позитивных услуг. Например, права на государственную защиту правовой свободы, права на публично-властное обеспечение безопасности. Иными словами, это своего рода гарантии прав человека.

Теперь, когда есть общее понимания прав человека, проследили путь развития, то можно перейти к самим проблемам.

Основными направлениями деятельности органов внутренних дел по обеспечению реализации, охране и защите конституционных прав, свобод и законных интересов граждан России являются:

1. защита человека, его жизни, здоровья, прав, свобод и законных интересов независимо от пола, возраста, национальности и т.д.;

2. недопущение в своей деятельности незаконных ограничений и нарушений прав, свобод и законных интересов граждан;

3. непосредственная охрана декларируемых Конституцией Российской Федерации прав, свобод и законных интересов граждан;

4. обеспечение необходимых условий реализации гражданами соответствующих видов прав, свобод и законных интересов.

Кроме того, надо сказать, что сотрудники органов внутренних дел обладают правом и полномочиями по ограничениям прав человека, соответственно это накладывает на них определенную ответственность, связанную с тем, чтобы сотрудники действовали в рамках закона, то есть законность - это важнейший фактор обеспечения прав человека. Что такое законность? Ученые не раз обращались к этому вопросу. Например, профессор В.С. Афанасьев рассматривает законность как принцип, метод и режим соответствия поведения участников общественных отношений и результатов норм права, выражающихся в законах, а В.Н. Кудрявцев в свою очередь определяет законность как обеспечение и защиту прав и свобод человека и гражданина со стороны государственных органов и должностных лиц, создание механизма обеспечивающих проведение норм права в жизнь.

Основными методами деятельности надзорные органы в обеспечении прав человека, являются:

- убеждение - передача нравственных, интеллектуальных, эмоциональных и других представлений от одного субъекта к другому. Это является наиболее привычным способом влияния на людей, которое 
должно воспитать у человека чувство необходимости соблюдения законов и правомерного поведения. То есть надзорные органы воздействует на людей, для соблюдения ими осознано законов и с целью повышения их правосознания и правовой культуры.

- $\quad$ принуждение - включает в себя различные формы и меры. Существует административное и уголовно-процессуальное принуждение. Этот метод подкреплен правом применения сотрудниками физической силы, специальных средств и огнестрельного оружия.

Надо сказать, что существуют различные формы принуждения:

1. Обеспечение доказательств по делу - необходимо доказать событие преступления, виновность лица, мотивы совершенного им преступления, и те обстоятельства, которые оказали влияние на степень и характер ответственность обвиняемого.

2. Пресечение правонарушений - эта форма характеризуется мерой пресечения (например, заключение под стражу, подписка о невыезде). Это необходимо для предотвращения возможностей преступника скрыться от правосудия, или совершения новых преступлений.

3. Предупреждение правонарушений - надзорные органы должны так воздействовать на человека, чтобы он решил, что не стоит исполнять свое преступное деяние. Данная форма включает в себя: проверка документов, обыск, следственный эксперимент, осмотр места происшествия, официальное предостережение.

Важное место в деятельности органов внутренних дел по обеспечению прав и свобод человека занимают организация и осуществление предупредительной, профилактической работы как наиболее эффективного и гуманного способа борьбы с преступлениями и иными правонарушениями. Профилактические мероприятия, которые осуществляются в процессе управления внутренними делами, состоят из:

- Общая профилактика - выявление и устранение причин и условий, способствующих совершению правонарушений.

- Индивидуальные профилактические - это меры, применяемые непосредственно к личности с антиобщественными установками и ориентациями для того, чтобы убедить ее в необходимости законопослушного поведения.

Роль органов внутренних дел в обеспечении прав и свобод граждан определяется как уже было сказано объемом и содержанием компетенции. Компетенция органов внутренних дел в сфере обеспечения прав и свобод человека и гражданина -это совокупность полномочий в этой сфере, возложенных на отдельные структурные подразделения. В обобщенном виде эти полномочия можно разделить на несколько групп:

- Полномочия в сфере охраны общественного порядка;

- Полномочия в сфере обеспечения общественной безопасности;

- Полномочия, связанные с проведением дознания и предварительного следствия;

- Иные полномочия, связанные с обеспечением прав и свобод человека и гражданина.

Не стоит забывать, что в процессе применения норм права, на заключительной стадии, выносится решение, которое фиксируется в правоприменительном акте. Данный акт должен быть в рамках закона, должен быть обоснован, целесообразен, справедлив.

Можно ли говорить о том, что надзорные органы справляются со с отведенной им ролью? Действительно ли прокуратура осуществляет достаточно эффективно возложенные на нее функции? Об этом можно говорить, руководствуясь уровнем 
доверия со стороны граждан. Потому что ничто иное как общественное мнение людей показывает то, насколько прокуратура справляется со своими обязанностями.

Таким образом, мы видим, что надзорные органы играют ключевую роль в обеспечении прав человека, однако, они должны действовать в рамках закона, потому что имеют достаточно широкий спектр полномочий и поэтому не должны превышать их или использовать там, где это не имеет необходимости. Обеспечение прав человека служебно-правовыми средствами и формами, применяемыми в деятельности правоохранительных органов важное условие реализации конституционной обязанности Российской Федерации как государства - признавать, соблюдать и защищать права и свободы человека.

Нельзя забыть, что немалую роль в обеспечении прав человека играют органы внутренних дел. Именно эти органы обладают рядом широких полномочий и средств, которые позволяют им защищать права человека и контролировать их реализацию. Важное место здесь занимает именно предупреждение преступлений, только тогда, когда преступник будет знать о неотвратимости наказания, он не будет совершать преступления. Здесь же надо сказать и о профилактической работе, проводимой сотрудниками органов внутренних дел как общей, так и индивидуальной, которая помогает наиболее гуманно предупредить преступления.

К сожалению, существующие проблемы обеспечения прав человека, ставят под угрозу авторитет власти, а люди чувствуют себя незащищенными, кроме того, это приводит к волнениям в обществе, что в свою очередь ведет к нестабильности и недоверии к государственной власти. Преодоление таких проблем, помогло бы обеспечивать права человека и пресекать правонарушения еще до их совершения. Это бы повысило уровень доверия граждан к правительству и к правоохранительным органам, а также поднялся бы уровень правосознания граждан, а это немаловажный элемент правового государства.

$$
* * *
$$

1. "Всеобщая декларация прав человека" от 10.12 .1948 (доступ из справочной правовой системы Консультант Плюс - http://www.consultant.ru)

2. Международный пакт о гражданских и политических правах от 16.12 .1966 (доступ из справочноправовой системы Гарант - http://base.garant.ru)

3. Конституция РФ от 12.12 .1993 (доступ из справочно-правовой системы Консультант Плюс http://www.consultant.ru)

4. Федеральный конституционный закон от 26.02.1997 N 1-ФКЗ "Об Уполномоченном по правам человека в Российской Федерации" (доступ из справочно-правовой системы Консультант Плюс http://www.consultant.ru)

5. Федеральный закон "О прокуратуре Российской Федерации" от 17.01.1992 N 2202-1-Ф3 (доступ из справочно-правовой системы Консультант Плюс - http://www.consultant.ru)

6. Гражданский кодекс Российской Федерации (ч.2) 26 января 1996 года N 14-Ф3 (доступ из справочно-правовой системы Консультант Плюс - http://www.consultant.ru)

7. Алменов Б.А. Проблема обеспечения гарантий прав и свобод человека. - 2012 // «Современная социология и образование», Великобритания (Лондон), 20-27 октября 2012 г., стр.102-103

8. Власенко Н.А. Теория государства и прав: учебное пособие Проспект, 2014, стр.192-207

9. Воситов Х.А. Некоторые вопросы правового механизма обеспечения прав и свобод граждан // Юриспруденция 2018, стр.54-60

10. Гусева А.Л. Механизм защиты конституционных прав и свобод человека и гражданина в РФ: к постановке проблемы // ISSN 1997-292Х № 1 (5) 2020, стр.61-62

11. Доклад Уполномоченного по правам человека в Российской Федерации за 2016 год от 17 мая 2017г., стр.11-39

12. Доцкевич М.В. Защита прав и свобод личности в деятельности надзорные органы как способ предупреждения правонарушений // Журнал «Юридическая наука и правоохранительная практика» № 1(27) ’2014, стр.20-26

13. Радько Т.Н. Теория государства и права: учебник для бакалавров Проспект, 2019 стр. 401-421

14. Рахматулин А.Ф. Особенности правового статуса личности в современном обществе // Журнал «Юридическая наука и практика: Вестник Нижегородской академии МВД России», 2018, стр. 198202 


\title{
РАЗДЕЛ ІІ. ПРАВО. ОБЩИЕ ВОПРОСЫ
}

\author{
Кабакова А.О. \\ Судьба стадии возбуждения уголовного дела \\ Крымский юридический институт (филиал) Университета прокуратуры \\ Российской Федерации \\ (Россия, Симферополь)
}

doi:10.18411/spc-20-08-2020-02

idsp: sciencepublic-20-08-2020-02

Рассматривая вопрос проблематики в уголовном процессе и на стадии возбуждения уголовного дела, следует указать на то, что необходимость самого существования возбуждения уголовного дела как самостоятельной стадии уголовного процесса ставится под сомнение рядом авторов.

Так, С.А. Грачев и А.С. Александрова считают, что стадия возбуждения уголовного дела является пережитком советской модели уголовного процесса и посему дальнейшее реформирование уголовно-процессуального законодательства неизбежно приведет к ее ликвидации. Такого же мнения придерживается С.Е. Вицин, указавший, что современное уголовно-процессуальное законодательство не нуждается в такой стадии, как возбуждение уголовного дела.

Большинство сторонников идеи о ликвидации стадии возбуждения уголовного дела как таковой в поддержку своего мнения апеллируют опытом зарубежных стран. В частности, достаточно часто в качестве примера указывается Уголовнопроцессуальный кодекс Украины, в котором сама по себе данная стадия упразднена и слита со стадией предварительного расследования.

Некоторые авторы приходят к выводу о том, что стадия возбуждения уголовного дела сильно «тормозит» уголовно-процессуальную деятельность, препятствуя эффективному расследованию уголовных дел. Однако, как утверждает А.Ф. Волынский, необходимо уделять не столько внимания содержанию норм уголовнопроцессуального законодательства зарубежного государства, сколько практике их применения. И как следует из ситуации на Украине, столь кардинальные изменения в уголовном процессе страны были не необходимостью, а лишь политическим инструментом, служившим интересам переходу к евростандартам.

Помимо всего прочего, сторонники ликвидации стадии возбуждения уголовного дела в качестве аргумента в защиту своей позиции ссылаются на Устав уголовного судопроизводства Российской империи 1864 года, в котором предусматривалось: «Жалобы почитаются достаточным поводом к начатию следствия. Ни судебные следователи, ни прокурор не могут отказать в том лицу, потерпевшему от преступления или проступка».

Идея об отказе от стадии возбуждения уголовного дела в современном уголовном судопроизводстве обсуждается не только в научных кругах, но и некоторыми практическими деятелями правоохранительных органов. Так члены расширенной рабочей группы при Министерстве внутренних дел РФ (далее - МВД РФ) сформировали такую модель уголовного процесса, при которой следователь, дознаватель, орган дознания сразу приступают к производству уголовного дела при наличии заявления, сообщения о преступлении. Представленная концепция начала уголовного судопроизводства представляется очень заманчивой, так как в своей структуре не предусматривает принятия решения об отказе в возбуждении уголовного дела, что с позитивной стороны повлечет за собой обеспечение прав и законных 
интересов заявителей, прежде всего - потерпевших от преступлений, а также обеспечит своевременное реагирование на признаки преступления и успешную борьбу с преступностью.

Однако даже для такой аргументированной концепции можно найти и контраргументы. И первый из них закреплен в ч.3 ст.55 Конституции РФ, который гласит, что права и свободы человека и гражданина могут быть ограничены федеральным законом только в той мере, в какой это необходимо в целях защиты основ конституционного строя, нравственности, здоровья, прав и законных интересов других лиц, обеспечения обороны страны и безопасности государства. Соответственно, ограничение таких конституционных прав личности, как право на свободу и личную неприкосновенность, неприкосновенность жилища, тайну переписки, телефонных разговоров и других прав допускается уголовно-процессуальным законодательством в той мере, в которой это необходимо для защиты прав и законных интересов личность и общества в целом. Применение мер процессуального принуждения, а также проведение следственных действий, которые связаны с правоограничением будут оправданы только в тех случаях, когда речь будет идти о расследовании конкретных преступлений, а не о проверке доводов заявления. Стадия возбуждения уголовного дела и является тем разграничительным барьером, который одновременно позволяет защищать лиц, потерпевших от преступления, и иных лиц, чьи права могли бы быть нарушены вследствие проведения незаконным и необоснованных следственных действий.

Учитывая то, что порой доступных процессуальных действий на стадии доследственной проверки недостаточно для того, чтобы возбудить уголовное дело представляется возможным, что законодатель и дальше пойдет по пути дальнейшего расширения процессуальных средств доследственной проверки, предусмотрев в уголовно-процессуальном законодательстве возможность проведения до возбуждения уголовного дела любых необходимых следственных действий в случаях, когда иным образом (без их производства) невозможно принять решение о наличии или отсутствии основания для возбуждения дела.

Таким образом, и стадия возбуждения не утратит своей важности и будет и дальше служить барьером от неправомерных ограничений прав человека и гражданина, а проведение тех процессуальных действий, которые необходимы для точного определения наличия либо отсутствия в деянии состава преступления позволят в полной мере защитить права лиц, потерпевших от преступления. При этом это также послужит процессуальной экономии, поскольку ряд процессуальных действий не придется проводить ввиду того, что они были осуществлены на стадии доследственной проверки.

$$
* * *
$$

1. Александров, А. С. Проект нового порядка открытия уголовного расследо-вания по сообщению о преступлении / А. С. Александров, С. А. Гра-чев.//Уголовный процесс. -2015. - № 7. - С. 14 - 21

2. Вицин С.Е. Институт возбуждения дела в уголовном судопроизводстве // Российская юстиция. М.: Издательская группа «Юрист». - 2003. - № 6.

3. Волынский А.Ф., Волынский В.В. Новый УПК Украины - ответ на вызовы современной преступности или...? // Российский следователь. - М: Издатель-ская группа «Юрист». - 2013. №5. С. 39-43

4. Кругликов А.П. Нужна ли стадия возбуждения уголовного дела в современ-ном уголовном процессе России? - Российская юстиция, 2011, №6, с.57

5. Петрухин И.Л. Возбуждение уголовного дела по действующему УПК РФ // Государство и право. -2005 . - № 1. - С. 67 .

6. [Электронный pecypc] // https://xn--b1aew.xn--p1ai/document/829054 


\section{Смирнов О.В. \\ Юридический процесс и процедура: понятие, сущность, различия}

Владимирский юридический институт ФСИН России

(Россия, Владимир)

doi:10.18411/spc-20-08-2020-03

idsp: sciencepublic-20-08-2020-03

\section{Аннотация}

Настоящая статья посвящена, прежде всего, проблематике процедуры подготовки проектов нормативных правовых актов и поиску путей решения выявленных проблем.

Ключевые слова: нормативно-правовой акт, законодательство, законодательный процесс, процедура подготовки нормативно-правового акта.

\section{Abstract}

This article is devoted, first of all, to the problems of the procedure for preparing draft regulatory legal acts and the search for ways to solve the identified problems.

Keywords: normative legal act, legislation, legislative process, procedure for preparing a normative legal act.

На сегодняшний день в Российской Федерации (Далее РФ) система законотворчества, а, вместе с ней и правовая система, нуждаются в обязательном упорядочивании, систематизации и согласованности нормативно - правовых актов (Далее НПА).

Основной источник, регламентирующий законодательный процесс в России Конституция РФ, однако, полноценного и легального определения самого процесса не существует. Равно, как нет четкого понятия и для «процедуры» в системе правотворчества. Вместе с тем процедурность синонимичная с нормативностью, реализовала себя в правовом регулировании, где существуют многочисленные и разнообразные процедурные отрасли: гражданское право, уголовно право, семейное право и так далее.

Процедурный механизм процесса законотворчества является важнейшей и неотделимой частью механизма всего правового урегулирования, так как процедура касается не только реализации, но и создания, а также отмены юридических норм.

Именно из-за отсутствия юридически грамотно оформленного и нормативнозакрепленного понятия, определяющего значение «процедура» и «процесс», возникают закономерные трудности в восприятии и последующей реализации некоторых НПА.

Так что же всё-таки несут в себе понятия «процедура» и «процесс» и в чем их различия? Возможно ли, что эти понятия тождественны, тогда почему реализация процедуры не возможна без процесса и наоборот? Для ответа на эти вопросы необходимо определиться, для начала, с такими понятиями как законодательство и законотворчество.

Правотворчество - это деятельность по созданию (изменению или отмене) правовых норм. Правотворчество классифицируется в зависимости от субъекта, принимающего основное участие в самом процессе. Так выделяют правотворчество народа (референдум); правотворчество государственных органов (федеральных и субъектов федерации); корпоративное правотворчество (локальное правотворчество организаций).

Законодательство - это совокупность федеральных и региональных НПА, действующих в стране. Исходным элементом системы права является правовая норма, а первичным элементом системы законодательства - нормативный акт. Элементы системы законодательства тоже обладают признаками единства и различия, 
соподчиненности, дифференциации, способности к обособлению. В основе системы законодательства лежат такие институты как право, судебная система и система государственного управления, которые направлены на обеспечение правого поля в государстве и слаженных действий всех правовых институтов, например силовые ведомства, судебная система и иные.

Правотворческая деятельность - это определенная операция с неким набором стадий, последовательность, регламентированная и урегулированная правом, направленная на достижение определенного результата. В основе правотворчества лежит любая юридическая процедура, которая направлена на упорядочивание осуществления юридической деятельности. Как правило, она четко изложена и нормативно закреплена. В рамках этой правотворческой процедуры наиболее разработана законодательная процедура, то есть процедура издания законов.

Выделяют следующие стадии законодательной процедуры:

1. Реализация права законодательной инициативы, то есть право официального внесения законопроекта в высший представительный орган страны, который в таком случае обязан рассмотреть данный законопроект. Субъекты права законодательной инициативы в РФ перечислены в ст. 104 Конституции. 2. Стадия обсуждения законопроекта, которая в РФ происходит на заседании Государственной Думы. 3. Стадия принятия законопроекта путем референдума в Государственной Думе, одобрения Советом Федерации и подписания Президентом России. Детально эта процедура регулируется Конституцией и регламентами деятельности высших органов государственной власти. 4. Стадия официального опубликования закона.

На наш взгляд последовательность осуществления этих стадий (процедур) можно считать процессом законотворчества. Представим, что процесс - это совокупность взаимосвязанных видов деятельности, которые используют входы для достижения предполагаемых результатов, тогда «предполагаемый результат» процесса - выход. Чтобы достичь этого результата, необходимы определенные методы осуществления деятельности процесса - процедуры. То есть, если процесс - это движение, то процедура - это некий набор правил, который указывает, как это движение выполнять.

Говоря о юридической процедуре, стоит отметить, что она направлена на реализацию норм материального права и основанных на них материальных правоотношений, которые охраняются от нарушений правовыми санкциями. Юридической процедуре, как и любой иной присущи определенные признаки, а именно: она ориентирована на достижение конкретного правового и или социального результата; состоит из последовательно сменяющих друг друга актов поведения и как деятельность внутренне структурирована правовыми отношениями; обладает моделью развития, предварительно установленной на нормативном или индивидуальном уровне; иерархически построена; постоянно находится в динамике, развитии; выступает средством реализации основного, главного для нее правового отношения.

Неотделима от понятия «юридическая процедура» категория основного правоотношения, то есть правоотношения, ради которого процедура возникает и реализации которого служит. По признаку основного отношения процедуру в правовой системе можно разделить на материальную, процессуальную и правотворческую. Основное правоотношения для материальной процедуры - регулятивное материальное правоотношение, где цель - осуществление позитивного поведения участников процесса. Для правотворческой процедуры характерно правоотношение, единственная цель которого, формирование правовых норм.

Процедура должна быть последовательной и обладать вариативностью в реализующем праве. Помимо прочего, один и определяющих факторов процедуры - ее доступность и детализация. Фактически, имеется в виду, как доступ к информации о способах и возможностях реализации те или иных законодательных процедур, так и 
проработка всех стадий запуска механизма юридической процедуры. Процедура должна быть надежной и выступать в роли гаранта положительного результата.

Для надежности процедуры необходима детальная и многофакторная проработка. Так же любой нормативной модели необходима отработка по временному параметру, то есть испытание временем. Именно из-за загруженности процедуры она требует на первоначальном этапе от законодателя постоянного анализа для быстрого реагирования при возникновении трудностей и срывов в ее нормативной работе. Нормативной процедуре присуща неотступная строгая очередность последовательных действий.

Таким образом, процедура, на наш взгляд, должна определять: свое целевое назначение; тип основных отношений круг лиц, участвующих в ней; акты поведения, которые должны совершить участники процедуры; последовательность совершения актов поведения; сроки (время) и место осуществления как отдельных процедурных действий, так и процедуры в целом; правовые средства, обеспечивающие функционирование процедуры.

Проанализировав все вышеизложенное, необходимо выделить сходство и различие процесса и процедур, отвечая на вопрос о тождественности этих двух понятий.

1) процесс относится к какому-либо явлению в целом, а процедура - всего лишь к поведению; 2) процесс включает элемент последовательности просто по самой своей природе (именно поэтому, применительно к нему и принято говорить о закономерном развитии явления), в то время как процедура носит более «рукотворный» характер, то есть может и не быть последовательной (например, если в официально установленном порядке пропущено какое-нибудь логически необходимое звено); 3) в отличие от процедуры, у процесса сугубо официальная «привязка» отсутствует.

Нами были изучены три позиции по вопросу соотношения понятий «процесса» и «процедуры».

Первая из них уделяет более широкое значения юридической процедуре, при этом юридический процесс выступает лишь разновидностью одноименной процедуры. Вторая позиция говорит о синонимичности этих двух понятий. Данная позиция основывается на том, что нет необходимости разграничивать смысловую нагрузку в отношении одних и тех же явлений. Третья позиция основывается на преобладании правового процесса над юридической процедурой.

На наш взгляд третья позиция является самой логичной, так как понятие процесса наделяется по отношению к процедуре более широким значением. Соответственно, процедура рассматривается в качестве части процесса. Таким образом, понятия «процесс» и «процедура» не идентичны и понятие правового процесса в соотношении с одноименной процедурой представляется более объемным.

Из всего вышесказанного можно сделать вывод, что понятия «процесса» и «процедуры» не являются тождественными, однако оба эти понятия обладают этапностью действий.

На сегодняшний день из-за отсутствия понятий «процесса» и «процедуры» правотворчества затрудняется их разграничение. В связи с данной проблемой нами были разработаны следующие определения:

Процедура в правотворчестве - это определенный, нормативно закрепленный порядок действий в правотворческом процессе, ориентированный на принятие, изменение или отмену нормативно-правового акта, в то время как процесс в правотворчестве - это закономерный ход развития какого-либо явления.

$$
* * *
$$

1. Конституция Российской Федерации (принята всенародным голосованием 12.12.1993 г.) (с учетом поправок, внесенных Законами РФ о поправках к Конституции РФ от 30.12.2008 г. № 6-ФКЗ, от 
30.12.2008 г. № 7-ФКЗ, от 05.02.2014 г. № 2-ФКЗ, от 21.07.2014 г. № 11-ФКЗ) // Собрание законодательства РФ. - 2014. - № 31. - Ст. 4398.

2. Синюков С.В. О понятии правотворчества. // Известия Саратовского университета, - 2011. C.113.

3. Бялт В.С., Трипутин С.Н. Законотворчество как вид правотворчества: теоретико-правовая характеристика. /В.С. Бялт., С.Н. Трипутин// Вестник Санкт-Петербургского университета МВД № 2. Спб., - 2016. - С. 35.

4. Бошно С.В. Система права и система законодательства. Право и современные государства. М., 2013. - C. 5.

5. Борисов А.С. К вопросу о понятии правотворчества. // Вестник государственного и муниципального управления. № 3. Орел., - 2014. - С. 33.

6. Исаев И.Э. Юридический процесс и юридическая процедура. //Вестник Московского университета МВД России. М., - 2011. - С.129.

7. Мамай Е.А. Модель юридической процедуры как технико-юридическая конструкция. // Журнал: Юридическая техника. - 2013. - № 7 (ч.2). - С. 465.

8. Соколов T.B. Процесс vs. процедура: синонимичные понятия или различные правовые явления? (теоретические аспекты). // Журнал: Юридические записки. СПб., - № 2. - С. 31.

\section{Трубицына Д.С. \\ Адвокатура и адвокатская деятельность в Российской Федерации: проблемы специализации}

ФГБОУ ВО «Российский государственный университет туризма»

(Россия, Черкизово)

doi:10.18411/spc-20-08-2020-04

idsp: sciencepublic-20-08-2020-04

Научный руководитель

Вражнов А.C.

\section{Аннотация}

Данная статья посвящена обоснованию авторской позиции о целесообразности введения специализации в российской адвокатуре и адвокатской деятельности.

Ключевые слова: адвокат, адвокатура, адвокатская деятельность, специализация в адвокатуре, общеюридическая практика, статус адвоката.

\section{Abstract}

This article is devoted to substantiating the author's position on the expediency of introducing specialization in the Russian advocacy and advocacy work.

Keywords: lawyer, advocacy, advocacy work, specialization in the advocacy, General legal practice, lawyer status.

Прежде чем перейти к теме исследования, необходимо определиться с понятиями «адвокат», «адвокатская деятельность», «адвокатура», при этом не будем основываться на официальных дефинициях, закрепленных в статьях 1-3 Федерального закона «Об адвокатской деятельности и адвокатуре в Российской Федерации» [1], а предложим свои определения:

1) адвокат - это лицо, профессией которого является оказание квалифицированной юридической помощи физическим лицам (гражданам, иностранным гражданам, лицам без гражданства) или юридическим лицам (российским и иностранным организациям);

2) адвокатская деятельность - это квалифицированная юридическая помощь, а также институт правовой системы Российской Федерации и гражданского общества, обеспечивающий защиту прав, свобод и законных интересов физических и юридических лиц, а также доступ к правосудию; 
3) адвокатура - это профессиональное сообщество, состоящее из адвокатов, оказывающих квалифицированные юридические услуги.

Как указано в пункте 2 статьи 2 Федерального закона «Об адвокатской деятельности и адвокатуре в Российской Федерации» [1], в рамках оказания юридической помощи адвокат дает консультации, составляет жалобы и заявления, представляет интересы доверителя в различных видах судопроизводства и пр.

Следовательно, целями адвокатской деятельности являются:

- защита прав, свобод и законных интересов доверителей, направленная на обеспечение правового статуса личности в Российской Федерации;

- гарантирование доступа к правосудию, т.е. признание за лицами, потерпевшими от правонарушений и преступлений, а также пострадавших от гражданско-правовых деликтов, возможности на защиту их прав, свобод и законных интересов в судебном порядке.

Реализуя указанные цели, адвокат должен быть специалистом в разрешении конкретной ситуации, которая возникла у его клиента.

Исходя из требований статей 9-12 Федерального закона «Об адвокатской деятельности и адвокатуре в Российской Федерации» [1], перед получением правового статуса адвоката, необходимо сдать квалификационный экзамен, оценивающий уровень теоретических и практических знаний претендента, к которому нужно получить допуск. Первоначально, претендент предоставляет в квалификационную комиссию адвокатской палаты субъекта Российской Федерации заявление о присвоении ему статуса адвоката, копию документа, удостоверяющего его личность, анкету, содержащую биографические сведения, копию трудовой книжки или иной документ, подтверждающий стаж работы по юридической специальности, копию документа, подтверждающего высшее юридическое образование либо наличие ученой степени по юридической специальности. Далее, в течение двух месяцев квалификационная комиссия организует проверку достоверности документов и сведений, представленных претендентом и принимает решения о допуске к самому квалификационному экзамену, проводимом в соответствии с Положением о порядке сдачи квалификационного экзамена на присвоение статуса адвоката [2]. Квалификационный экзамен состоит из письменных ответов на вопросы из всех отраслей права (тестирования), а также аналогичного устного собеседования по билетам.

После сдачи квалификационного экзамена и принесения соответствующей присяги, новоявленный адвокат может выбрать один из следующих профессиональных путей:

- заниматься общеюридической практикой;

- выбрать отдельное направление (отдельную специализацию).

Адвокатская деятельность, как правило, многофункциональна и многогранна, может одновременно затрагивать несколько направлений, следовательно, большее число новоявленных адвокатов предпочитают заниматься общеюридической практикой.

Вместе с тем, доверителю в рамках разрешения определенного дела, зачастую, требуются узкоспециализированные юридические услуги. Адвокат, специализирующийся в определенной тематике, например, бракоразводные процессы или налоговые проверки, естественно, превосходит по своим знаниям адвоката общего профиля, т.к. имеет представление не только о нормах закона в данной отрасли права, но и соответствующую правоприменительную (следственную, судебную и пр.) практику. Следовательно, данный адвокат способен найти более эффективные и необычные решения, которые неизвестны адвокату общего профиля, т.к. у него накоплен больший практический опыт в разрешении именно данной категории дел, а также затратить гораздо меньше времени на изучение данного вопроса. 
В подтверждение нашего мнения о целесообразности специализации в адвокатуре, приведем высказывание одного из дореволюционных мэтров адвокатуры Е.В. Васьковского. Исходя из его авторитетной позиции, «адвокатура представляет собой защитницу индивидуальных прав граждан во имя и в интересах общественного блага и является таким же фактором правосудия, как суд и прокурорский надзор. Адвокат выступает в процессе не в качестве заместителя своего клиента, так как этим заместителем служит поверенный, а в качестве уполномоченного общества, подобно уполномоченному государства - прокурору. Адвокат защищает не личные выгоды тяжущегося, а общественный интерес точно таким же образом, как прокурор охраняет не пользу потерпевшего, а правовой порядок и безопасность всего государства» [3, С. 287]. Трактуя данное высказывание применительно к теме нашего исследования, представляется, что только узкоспециализированный адвокат, имеет возможности и способен осуществлять полноценную защиту индивидуальных прав и свобод человека в конкретной жизненной ситуации.

Юридические направления, в которых адвокаты могут специализироваться, достаточно многочисленны: арбитражные дела, уголовные дела, земельно-правовые споры, наследственные споры, трудовые конфликты и пр. В настоящее время, исходя из правоприменительной практики, наиболее востребованными направлениями являются: адвокат по уголовным делам, адвокат по делам об административных правонарушениях, налоговый адвокат, корпоративный адвокат.

Подводя итог настоящей статье, подчеркнём, что вопрос специализации адвоката остается актуальным и на сегодняшний день. Несмотря на распространенность общеюридической деятельности адвоката, как уже было указано выше, специалист, осуществляющий узконаправленную деятельность, будет намного успешнее и профессиональнее в своей карьере.

$$
* * *
$$

1. Федеральный закон от 31.05.2002 №63-Ф3 «Об адвокатской деятельности и адвокатуре в Российской Федерации» // СПС «КонсультантПлюс».

2. Положение о порядке сдачи квалификационного экзамена на присвоение статуса адвоката (утв. Советом Федеральной палаты адвокатов 25.04.2003, протокол №2) // СПС «КонсультантПлюс».

3. Васьковский Е.В. Основные вопросы адвокатской этики. Спб, 1985 г. / Традиции адвокатской этики. Избранные труды российских и французских адвокатов (XIX - начало XX в.). Составители И.В. Елисеев, Р.Ю. Панкратов. - Спб.: Изд-во «Юридический центр Пресс». - 2004. - 368 с.

\section{Цвик Е.Б., Ярощук И.А. \\ Специфика молодёжного экстремизма в России}

Белгородский государственный национальный исследовательский университет (НИУ «БелГУ») (Россия, Белгород)

doi:10.18411/spc-20-08-2020-05

idsp: sciencepublic-20-08-2020-05

В конце XX столетие на долю российского общества выпало много испытаний в виде дезорганизации социальных, экономических, политических норм и институтов, неопределённости и нестабильности условий жизнедеятельности, что повлекло состояние духовно-нравственного кризиса и утрату ценностно-нормативных ориентиров. Последствия этого сложного периода до сих зримо ощущаются в обществе в виде девиантного поведения, одним из распространённых проявлений которого является экстремизм, всё глубже проникающий в молодёжную среду. В первые десятилетия XXI века данная проблема приобретает особую остроту, представителями молодого поколения часто совершаются агрессивные действия, преступления, создающие благоприятные условия для зарождения экстремистской 
идеологии. Действительно, особую опасность представляет привлечение в свои ряды экстремистскими сообществами молодых людей, на умы которых легче всего повлиять посредством современных телекоммуникационных и информационных технологий.

Для молодёжи, ещё на имеющей прочных идеологических установок, характерны максималистские взгляды, формирующиеся под влиянием различных социальных, политических, экономических факторов и создающие прочный фундамент радикальных, агрессивных и в итоге - экстремистских идей и взглядов. Вследствие чего молодые люди оказываются вовлечёнными в экстремистские и террористические организации.

В последнее время на территории Российской Федерации весьма определённо проявились национал-экстремистские, крайне левые и крайне правые, этноконфессиональные и сепаратистские начала экстремизма.

Все существующие и действующие в России радикальные общественные объединения, в ряды которых активно вовлекаются молодые люди, представляется возможным классифицировать в соответствии со следующими категориями:

- националисты (ксенофобы, неофашисты, неонацисты);

- радикалы: «оранжевые», радикальные коммунисты, анархисты;

- религиозные экстремистские объединения - ваххабиты, сатанисты и т.д.;

- экологические и культуроохранные «зелёные»- экстремистская деятельность осуществляется во имя защиты природы и окружающей среды, памятников культуры, борьбы с глобализацией;

- мимикранты - под прикрытием экстремистской деятельности осуществляют криминальные преступления, возраст от 17 до 23 лет, пользуются атрибутикой скинхедов, но с ними себя не ассоциируют.

- в качестве отдельной разновидности экстремистского объединения выделяются футбольные фанаты [1, с. 105].

Наиболее массовым молодёжным экстремистским движением в России считается движение скинхедов («бритоголовых»). Идеологическая организация данного движения далеко неоднозначна, так как выделяются и антифашисты - и неонацисты (наци-скинхеды, или НС-скинхеды). Наибольшую популярность в рамках нашего государства, начиная с 90-х гг. XX столетия, приобретают неонацисты, в основе мировоззренческих установок которых - воинствующий национализм и расизм, культовой личностью является Адольф Гитлер.

Основной лозунг скинхедов «Россия - для русских» явно указывает на основную направленность их деятельности, основными методами которой являются плакаты, надписи профашистского содержания, свастика и т.д., которые получают широкое распространение посредством телекоммуникационной сети Интернет.

Среди экстремистских движений выделяется также часто ассоциируемое со скинхедами движение РНЕ. Действительно, идеологические установки данных движений во многом схожи (неофашизм, расизм). Главная их цель - изменение конституционного строя России, а сами действия членов РНЕ имеют непосредственную направленность на разжигание национальной розни.

К агрессивным, экстремистским группировкам 80-90-х гг. XX века относятся люберы, гопники, не образующие определённой субкультуры, а имитирующие стиль и идеологию уличных банд и действующие аналогично криминальным группировкам. Их экстремистская активность направлена в отношении той или иной молодёжной группы, субкультуры в целом. Со второй половины 1990-х гг. происходит трансформация данного движения за счёт создания собственной субкультуры посредством отрицания права остальных на это (панков, рокеров, рэйверов, роллеров и др.). 
В случае со скинхедами - имеется возможность утверждать наличие определённой идеологии, когда их экстремизм непосредственно связан с осуществлением их программных целей, то в отношении гопников подобное утверждение невозможно, поскольку целью их активности является «сам культ силы в наиболее примитивных формах» [1, с. 107].

Таким образом, одним из ведущих факторов формирования экстремистских молодёжных движений в России является возрастающая в конце XX столетия пропаганда насилия, когда нацизм, нетерпимость к этническим и субкультурным обществам, представляет собой ответную реакцию не только на происходящие в стране социальные, политические, экономические процессы. Рост экстремизма среди молодёжи обусловливается и ростом уровня преступности в обществе. Очень часто экстремисты прикрывают свою деятельность идеологическими лозунгами, политическими акциями, а в реальности осуществляют криминальную деятельность.

Ещё одной наиболее распространённой субкультурной формой экстремистской молодёжной активности в современной России является сообщество футбольных фанатов, опасность которого очень велика, особенно, когда спортивные матчи проходят между командами, разными по национальности. В таких случаях столкновения болельщиков приобретают уровень противостояния агрессивной молодёжи под началом уже националистических лозунгов, когда дух спортивного состязания перерастает в этнополитический экстремизм, являющийся в большинстве случаев результатом манипуляции агрессивной активности молодёжи, подростков отдельными политическими силами.

В России выделяются и современные формы существования патриотических движений, которые во многом следуют философии славянофилов в её примитивной интерпретации (например, современное молодёжное движение типа ВАЛ), когда приверженность и сохранение русских традиций и их неприкосновенности приобретают крайнюю, агрессивную форму, и уже открыто звучат националистические настроения, а члены патриотических движений прямо говорят о приверженности русскому национализму.

Отличительной особенностью этнического экстремизма является использование патриотических настроений молодёжи в целях решения политических, экономических и других вопросов. Для этнического экстремизма характерны популистские лозунги, манипуляция самыми простыми природными инстинктами самосохранения и самоутверждения. Патриотизм в данном случае представляет собой лишь форму выражения личной агрессивной активности по отношению к идейным противникам, за его лозунгами скрывается истинная направленность.

В современной России активно набирает силу фашистское движение. Его возникновение многими исследователями традиционно относится к постсоветскому периоду. Для молодёжных фашистских объединений свойственно подражание немецкому нацизму (приветствие поднятой рукой, свастика, портреты Гитлера, чтение «Майн Кампф» и др.), но в то же время крайние проявления агрессии имеют направленность на выходцев из Азии, Кавказа и др. В отдельных случаях - это одна из форм русского национализма, обращение к православной культуре и к монархическим ценностям (например, РНЕ и их последователи).

Для представителей и последователей молодёжных фашистских объединений фашизм ассоциируется с наведением правопорядка, возрождением силы и могущества нации, утверждением национальной идеи и соблюдением прав человека, когда все проблемы могут быть решены предельно просто - за счёт уничтожения врага, то есть неарийца. В основе данной экстремистской идеологии оказывается мощный энергетический потенциал коллективной психологии молодёжных масс, направленный на борьбу со всем чужеродным. 
Серьёзный идеологический вызов целостности и стабильности молодёжи современной России, сделан со стороны радикального ислама, который определяется как салафизм или ваххабизм [2], для которого характерна «непримиримость к гражданскому светскому обществу, стремление заменить его исламом, который организован в соответствии с законом шариата, недопустимость раздельного существования религии и государства, противопоставление исламского мира остальным цивилизационным моделям, отрицание всех неисламских законов, проповедь религиозной нетерпимости, «джихада», религиозно мотивированного терроризма» [3].

«Экстремизм представляет особую опасность, так как, основываясь на идеях радикализма, фашизма и национализма, конвертирует их в крайние формы проявлений, что представляет серьёзную угрозу для общества и государства в целом» [4, с. 14]. Органами правопорядка современной России ведётся постоянная борьба с экстремистскими организациями, объединениями, группировками. В Российской Федерации за экстремистскую деятельность грозит уголовная, гражданско-правовая и административная ответственность.

Но даже с учётом принимаемых мер появляется новая информации об акциях националистических организаций. Телекоммуникационная сеть Интернет переполнена агрессивной активностью молодёжных экстремистских направлений и объединений, разжигающих межнациональные конфликты, наносящих оскорбления по национальному, религиозному признаку, в том числе и угрозы расправы, которые вполне могут иметь реальные последствия. Поэтому одной из главных функций государства является контроль ситуации и предотвращение открытых проявлений экстремизма.

$$
* * *
$$

1. Баева, Л. В. Философия молодежных движений: от пацифизма до экстремизма : монография / Л. В. Баева. - Астрахань : Астраханский государственный университет, Издательский дом «Астраханский университет», 2012. - 232 с.

2. Игнатенко. А. А. Эндогенный радикализм в исламе. - URL: https://ca-c.org/journal/cac-082000/12.ignatenko.shtml (дата обращения: 23.07.2020).

3. Васильев. А. М. Пуритане ислама? Ваххабизм и первое государство Саудидов в Аравии $1744 / 45$ 1818. URL: www.islam.ru (дата обращения: 24.07.2020).

4. Политический экстремизм: основные тенденции и причины эскалации: информационноаналитический вестник / под ред. А. П. Кошкина. Вып. 8. Москва : ФГБОУ ВО «РЭУ им. Г. В. Плеханова», 2017. - 96 с. 


\title{
РАЗДЕЛ ІІІ. ГРАЖДАНСКОЕ ПРАВО
}

\author{
Авдеева Н.И. \\ Признание и исполнение решений иностранных судов о взыскании алиментов на \\ территории Российской Федерации
}

ФГБОУ ВО «Юго-Западный государственный университет»

(Россия, Курск)

doi:10.18411/spc-20-08-2020-06

idsp: sciencepublic-20-08-2020-06

\section{Аннотация}

Статья посвящена особенностям правового регулирования признания и исполнения решений иностранных судов о взыскании алиментов на территории Российской Федерации. Проанализировано действующее законодательство в исследуемой области, внесены предложения по его совершенствованию.

Ключевые слова. Алиментные обязательства, судебные решения, признание, исполнение.

\section{Abstract}

The article is devoted to the specifics of the legal regulation of recognition and enforcement of decisions of foreign courts to recover alimony in the territory of the Russian Federation. The current legislation in the studied area is analyzed, suggestions for its improvement are made.

Keywords. Alimony obligations, court decisions, recognition, enforcement.

Неисполнение алиментных обязательств является, как мы считаем, проблемой каждого государства. Большое количество должников по алиментам как в развитых демократических странах с прогрессивной правовой системой, так и в развивающихся государствах. Неплательщики алиментов, к сожалению, обыденное явление как для Германии[21], так и для Белоруссии[22]. Так, по данным управления принудительного исполнения Министерства юстиции Республики Беларусь, за 2018 г. к судебным исполнителям поступило 45246 исполнительных документов о взыскании алиментов, в 2019 г. - 44 533[22]. Довольно большое количество алиментных должников Белоруссии либо проживают, либо работают в Российской Федерации. Должниками по алиментным обязательствам, возникшим за пределами России, могут быть как ее граждане, так и иностранцы, проживающие или работающие на территории нашего государства.

В соответствии с ч. 3 ст. 62 Конституции РФ, а также ст. 4 закона о статусе иностранных граждан на территории РФ, на иностранцев и лиц без гражданства практически в полной мере распространяет действие российское законодательство[14]. Однако в отношении находящихся на территории России иностранных плательщиков алиментов необходимо учитывать ряд особенностей. Первое на что стоит обратить внимание, не является ли такой плательщик лицом, обладающим дипломатическим иммунитетом? В этом случае, согласно нормам международного права[2,3], данные субъекты полностью находятся под юрисдикцией права страны их собственного проживания и, таким образом, исполнение ими алиментных обязательств будет происходить в соответствии с нормами алиментного законодательства их родного государства.

В случае если плательщик алиментов (гражданин России или иностранный гражданин) проживает, работает на территории Российской Федерации, а получатель находится за ее пределами и требуется принудительное исполнение алиментных обязательств на территории Российского государства, необходимо осуществить 
процедуру признания и исполнения решения иностранного суда на территории России. Данная процедура регламентируется нормами ГПК РФ (глава 45). Такое признание может быть осуществлено только на основе международного договора Российской Федерации с соответствующим иностранным государством[11]. Такие договоры у Российской Федерации есть только с рядом государств, таких как Вьетнам, Аргентина, Индия, Эстония, Молдова и некоторыми другими[5,6,7,8,9,10]. В Российской Федерации уже сложилась обширная судебная практика по такого рода делам[16,17].

Российским законодательством установлен трехлетний срок представления соответствующих решений иностранных судов в российские суды. При этом данные категории дел рассматриваются верховными судами республик, краевыми областными и другими приравненными к ним судами по месту нахождения плательщика алиментов, а если оно не известно, то по месту нахождения имущества[11, ст. 410]. К ходатайству иностранного гражданина должно прилагаться решение соответствующего иностранного суда. Надо отметить, что взыскание алиментов на основании решения иностранного суда будет происходить в соответствии с российским законодательством и в объеме, предусмотренном российским семейным законодательством. Так, областным судом было принято определение о разрешении принудительного исполнения решения иностранного суда на территории России и взыскании задолженности по уплате алиментов, превышающей трехлетний период, установленный ст. 113 СК РФ, на что указал ВС РФ в своем постановлении, изменив соответствующее решение нижестоящего суда[18]. В случае признания решения иностранного суда дальнейшее принудительное исполнение алиментного обязательства будет осуществляться в соответствии с законодательством об исполнительном производстве.

При отсутствии международного договора исполнение решения иностранного суда на территории России осуществляться не может. Так, СК по гражданским делам ВС РФ была отклонена частная жалоба Ф.Х. на определение Мособлсуда об отказе в удовлетворении её ходатайства о принудительном исполнении решения районного суда Панков/Вайсензее Федеративной Республики Германия от 14 января 2009 г. ВС РФ, также как и нижестоящая инстанция обосновал этот отказ отсутствием соответствующего международного соглашения между Россией и ФРГ[19]. Однако законодательство и судебная практика некоторых стран признает «в качестве условия признания и исполнения иностранных судебных решений взаимность»[20, с. 171]. Например, «Франция и Российская Федерация не связаны никаким международным договором в этой области. Вместе с тем французские суды признают и исполняют некоторые решения российских судов в случае, если они соответствуют условиям французского законодательства о признании иностранных судебных решений. Решения французских судов не подпадают под такой режим на российской территории»[20, с. 172]. Российская Федерация также до сих пор не ратифицировала Гаагскую Конвенцию о признании и исполнении решений, касающихся алиментов[4]. Но отдельные государства признают и исполняют решения иностранных судов о взыскании алиментов и на основании внутреннего законодательства. Например, в Финляндии по данным вопросам приняты два нормативных акта: «Закон о признании и исполнении иностранных судебных решений о взыскании алиментов (№ 370 от 1983 года) и Постановление о признании и исполнении иностранных судебных решений о взыскании алиментов в отдельных случаях (№ 832 от 1989 года)»[15].

Итак, в Российской Федерации решения иностранных судов о взыскании алиментов признаются только на основании двухстороннего соглашения. Считаем, что алиментные обязательства, особенно на несовершеннолетних детей, являются важной социальной гарантией для нуждающихся в помощи лиц вне зависимости от места их проживания, гражданства и страны, в которой вынесено соответствующее судебное решение об их взыскании. В этой связи вызывает уважение решения отдельных стран о признании и исполнении решений иностранных судов о взыскании алиментов на своей 
территории, основываясь на принципе взаимности, а также принятие внутренних законов, направленных на такого рода признания. Российской Федерации следует также пойти по пути этих стран.

$$
* * *
$$

1. Конституция Российской Федерации (принята всенародным голосованием 12.12.1993) (с учетом поправок, внесенных Законами РФ о поправках к Конституции РФ от 30.12.2008 № 6-ФКЗ, от 30.12.2008 № 7-ФКЗ, от 05.02.2014 № 2-ФКЗ, от 21.07.2014 № 11-ФКЗ)// Собрание законодательства РФ. 2014. № 31. Ст. 4398.

2. Венская конвенция о дипломатических сношениях (заключена в г. Вене 18.04.1961)// Ведомости ВС СССР. 29 апреля 1964 г. № 18. Ст. 221

3. Венская конвенция о консульских сношениях (заключена в г. Вене 24.04.1963)// Сборник международных договоров СССР, вып. XLV. М., 1991. С. $124-147$.

4. Конвенция о признании и приведении в исполнение решений, касающихся алиментных обязательств (Гаага, 2 октября 1973 г.)// ИПС Гарант

5. Договор между Российской Федерацией и Социалистической Республикой Вьетнам о правовой помощи и правовых отношениях по гражданским и уголовным делам (подписан в г. Москве 25.08.1998) (ред. от 23.07.2003)// Собрание законодательства РФ. 2012. № 42. Ст. 5682

6. Договор между Российской Федерацией и Аргентинской Республикой о сотрудничестве и правовой помощи по гражданским, торговым, трудовым и административным делам (подписан в г. Москве 20.11.2000)// Собрание законодательства РФ. 2003. № 30. Ст. 3040

7. Договор между Российской Федерацией и Республикой Индией о правовой помощи и правовых отношениях по гражданским и торговым делам (подписан в г. Нью-Дели 03.10.2000)// Собрание законодательства РФ. 2006. № 20. Ст. 2160

8. Договор между Российской Федерацией и Республикой Польша о правовой помощи и правовых отношениях по гражданским и уголовным делам (подписан в г. Варшаве 16.09.1996)// Собрание законодательства РФ. 2002. № 7. Ст. 634

9. Договор между Российской Федерацией и Республикой Молдова о правовой помощи и правовых отношениях по гражданским, семейным и уголовным делам (подписан в г. Москве 25.02.1993)// Собрание законодательства РФ. 1995. № 20. Ст. 1766

10. Договор между Российской Федерацией и Эстонской Республикой о правовой помощи и правовых отношениях по гражданским, семейным и уголовным делам (подписан в г. Москве 26.01.1993)// Собрание законодательства РФ. 1998. № 2. Ст. 229.

11. Гражданский процессуальный кодекс Российской Федерации от 14.11.2002 № 138-Ф3 (ред. от 24.04.2020)// Собрание законодательства РФ. 2002. № 46. Ст. 4532 (Собрание законодательства РФ. 2020. № 17. Ст. 2709)

12. Семейный кодекс Российской Федерации от 29.12.1995 № 223-Ф3 (ред. от 06.02.2020)// Собрание законодательства РФ. 1996. № 1. Ст. 16 (Собрание законодательства РФ. 2020. № 6. Ст. 589)

13. Федеральный закон от 02.10.2007 № 229-Ф3 (ред. от 08.06.2020) «Об исполнительном производстве»// Собрание законодательства РФ. 2007. № 41. Ст. 4849 (Собрание законодательства РФ. 2020. № 24. Ст. 3740)

14. Федеральный закон от 25.07.2002 № 115-Ф3 (ред. от 27.12.2019) «О правовом положении иностранных граждан в Российской Федерации»// Собрание законодательства РФ. 2002. № 30. Ст. 3032 (Собрание законодательства РФ. 2019. № 52 (часть 1). Ст. 7821).

15. Методические рекомендации по порядку исполнения требований исполнительных документов о взыскании алиментов (утв. ФССП России 19.06.2012 № 01-16)// Бюллетень Федеральной службы судебных приставов. 2012. № 8. (Методические рекомендации)

16. Определение СК по гражданским делам Верховного Суда РФ от 2 марта 2010 г. № 88-Г10-2// ИПС Гарант

17. Определение СК по гражданским делам Верховного Суда РФ от 26 января 2010 г. № 51-Г09-28 // ИПС Гарант

18. Обзор судебной практики Верховного Суда РФ от 01.03.2006 «Обзор судебной практики Верховного Суда Российской Федерации за четвертый квартал 2005 года»// Бюллетень Верховного Суда РФ. 2006. № 5.

19. Определение СК по гражданским делам Верховного Суда РФ от 1 декабря 2009 г. N 4-Г09-27// ИПС Гарант

20. Концевой Г.В. Признание и исполнение иностранных решений по делам о взыскании алиментов// Вестник Саратовской государственной юридической академии. 2015. № 1 (102). С. 170-174.

21. Как в Германии платят алименты URL// https:/www.dw.com/ru/как-в-германии-платят-алименты/a46170994 (дата обращения: 03.07.2020)

22. Задолженность по алиментам с 1 июля будут считать по-новому URL// https://pravo.by/novosti/obshchestvenno-politicheskie-i-v-oblasti-prava/2020/june/52050/(дата обращения: 03.07.2020) 


\section{Пожидаева А.С. \\ Конфискация орудия совершения или предмета административного правонарушения как вид административного наказания за правонарушение в сфере предпринимательской деятельности}

doi:10.18411/spc-20-08-2020-07

idsp: sciencepublic-20-08-2020-07

\section{Аннотация}

В статье рассматриваются особенности правового регулирования конфискации орудия совершения или предмета административного правонарушения как вид административного наказания за правонарушение в сфере предпринимательской деятельности. Рассмотрено понятие конфискации и особенности ее применения.

Ключевые слова: Административная ответственность, административное правонарушение, конфискация.

В соответствии со статьей 3.7 Кодекса об административных правонарушениях РФ [4] (далее - КоАП РФ) конфискацией орудия совершения или предмета административного правонарушения является принудительное безвозмездное обращение в федеральную собственность или в собственность субъекта Российской Федерации не изъятых из оборота вещей. Конфискация может назначаться в качестве как основного, так и дополнительного наказания. Основанием для назначения такого наказания является совершение правонарушения собственником конфискуемого имущества.

Конфискация может быть обращена исключительно на собственность правонарушителя, что подтверждает личный характер административного наказания[9]. Отчуждение имущества, не являющегося собственностью правонарушителя, свидетельствовало бы о нарушении основного принципа личной административной ответственности, согласно которому наказание может быть применено лишь к лицу, виновному в совершении противоправного деяния.

Часть 3 статьи 3.7 КоАП РФ устанавливает ряд случаев, которые нельзя признать конфискацией, в частности изъятие из незаконного владения лица, совершившего административное правонарушение, орудия совершения или предмета административного правонарушения: подлежащих в соответствии с федеральным законом возвращению их законному собственнику; изъятых из оборота либо находившихся в противоправном владении лица, совершившего административное правонарушение, по иным причинам и на этом основании подлежащих обращению в собственность государства или уничтожению.

Изъятие орудия совершения или предмета административного правонарушения в соответствии с частью 3 статьи 3.7 КоАП РФ у лиц, которые владеют данным имуществом на законных основаниях (например, в силу договора аренды), лишь на том основании, что оно используется с нарушением установленных законом требований, недопустимо [6]. Исключением из этого правила являются случаи, прямо предусмотренные законом (например, пунктом 1 статьи 25 Федерального закона от 22 ноября 1995 года № 171-Ф3 «О государственном регулировании производства и оборота этилового спирта, алкогольной и спиртосодержащей продукции» [5], которая посвящена пресечению незаконных производства и (или) оборота этилового спирта, алкогольной и спиртосодержащей продукции, а также незаконного использования основного технологического оборудования для производства этилового спирта, которое подлежит государственной регистрации).

Необходимо учитывать, что изъятие орудия совершения или предмета административного правонарушения в случае, когда это имущество в соответствии с законом изъято из оборота либо находится в противоправном владении лица по иным 
причинам и на этом основании подлежит обращению в собственность государства или уничтожению, не является конфискацией, то есть видом административного наказания, и предполагает лишение лица имущества, только если последний владеет им незаконно, а также не находится в прямой зависимости от факта привлечения к административной ответственности.

В теории уголовного права конфискация делится на общую и специальную. Под общей конфискацией понимается изъятие всего имущества осужденного [7], под специальной конфискацией понимается изъятие лишь определенных объектов. Объекты специальной конфискации делятся на имущества и иные доходы, полученные в результате совершения преступления, и орудия, средства и предметы преступления. Кроме того, в действующем Уголовном кодексе РФ [3] (далее - УК РФ) конфискация рассматривается не как наказание, а как иная мера уголовно-правового характера, которой посвящена Глава 15.1 УК РФ.

В отличие от УК РФ, в КоАП РФ конфискация является видом наказания и относится к специальной конфискации, так как может производиться только в отношении строго определенных имущественных объектов. Как правило это вещи, непосредственно связанные с административным противоправным деянием, указание на которые имеется как в описании данного вида административного наказания, так и в санкциях соответствующих статей Особенной части КоАП РФ. Например, часть 1 статьи 14.10 КоАП РФ предусматривает ответственность за незаконное использование чужого товарного знака, знака обслуживания, наименования места происхождения товара или сходных с ними обозначений для однородных товаров, санкция которой в числе прочих предусматривает конфискацию предметов, содержащих незаконное воспроизведение товарного знака, знака обслуживания, наименования места происхождения товара, а также материалов и оборудования, используемых для их производства, и иных орудий совершения административного правонарушения.

Интересным является вопрос о соотношении административной конфискации и конфискации, предусмотренной статьей 243 Гражданского кодекса РФ [2] (далее - ГК РФ). Согласно данной статье, конфискация возможна как в судебном порядке- по решению суда, так и в административном порядке- по решению компетентного органа государственной власти или уполномоченного должностного лица. Конфискация по ГК РФ относится к общей конфискации и включает в себя все движимое и недвижимое имущество лица. Кроме того, гражданско-правовая конфискация основывается на принципе эквивалентности и носит компенсационный характер, то есть изъятие обуславливается удовлетворением интересов любых участников гражданских правоотношений, в частности не только государства, но и частных лиц.

Согласно части 1 статьи 3.7 КоАП РФ конфискация назначается судьей. Статья 35 Конституции РФ [1] закрепляет незыблемые гарантии права собственности. Первая гарантия устанавливает следующее: никто не может быть лишен своего имущества иначе как по решению суда; вторая гарантия гласит, что принудительное отчуждение имущества, для государственных нужд может быть произведено только при условии предварительного и равноценного возмещения.

В силу статьи 3.3 КоАП РФ конфискация орудия совершения или предмета административного правонарушения относится к дополнительным видам административных наказаний, и как правило, применяется в совокупности с административным штрафом.

А.Н. Левин, А.А. Чувилов справедливо замечают, что при применении данного вида наказания на практике возникает ряд проблем. При назначении данного вида наказания, правонарушителю наносится прямой имущественный вред, тем самым принуждая его к соблюдению требований закона[8].

В частности, административные правонарушения в сфере таможенного дела (глава 16 КоАП РФ) в большинстве случаев совершаются лицами, которые 
осуществляют таможенные операции на профессиональном уровне и в качестве основного вида деятельности. И конфискация орудия совершения или предмета административного правонарушения в этой области деятельности является самым распространенным видом наказания. Однако, так как лица, осуществляющие таможенные операции, как правило, не являются собственниками конфискуемого имущества и не имеют экономической заинтересованности в сохранении этого имущества, следовательно, применение к лицам, осуществляющим таможенные операции, данного вида наказания не наносит им личного материального ущерба, а значит не достигает тех целей, которые стоят перед конфискацией.

Часто конфискация применяется Федеральной службой по регулированию алкогольного рынка (далее по тексту - Росалкогольрегулирования). В соответствии с Докладом об осуществлении государственного контроля

(надзора)

Росалкогольрегулирования в 2019 году по результатам проведённых мероприятий конфисковано 44212,44 декалитров этилового спирта и 265879,958 декалитров алкогольной продукции [10]. Вся изъятая продукция уничтожена.

В целом же, можно сделать вывод, что конфискацию как вид административного наказания за правонарушение в сфере предпринимательской деятельности применяют с целью, запретить совершение любого правонарушения, а так же с целью профилактики недопущения ранее совершенных правонарушений.

$$
* * *
$$

1. Конституция Российской Федерации (принята всенародным голосованием 12.12.1993) [с учетом поправок, внесенных Законами РФ о поправках к Конституции РФ от 30.12.2008 № 6-ФКЗ, от 30.12.2008 № 7-ФКЗ, от 05.02.2014 № 2-ФКЗ, от 21.07.2014 № 11-ФКЗ] // Собр. законодательства Рос. Федерации. - 2014. - № 31. - Ст. 4398.

2. Гражданский кодекс Российской Федерации (часть первая): федер. закон от 30.11.1994 № 51-Ф3 [ред. от 16.12.2019, с изм. от 12.05.2020] // Собр. законодательства Рос. Федерации. - 1994. - № 32. - Ст. 3301.

3. Уголовный кодекс Российской Федерации: федер. закон от 13.06.1996 № 63-Ф3 [ред. от 08.06.2020] // Собр. законодательства Рос. Федерации. - 1996. - № 25. - Ст. 2954.

4. Кодекс Российской Федерации об административных правонарушениях: федер. закон от 30.12.2001 № 195-Ф3 [ред. от 08.06.2020] // Собр. законодательства Рос. Федерации. - 2002. - № 1 (ч. 1). - Ст. 1.

5. О государственном регулировании производства и оборота этилового спирта, алкогольной и спиртосодержащей продукции и об ограничении потребления (распития) алкогольной продукции : федер. закон от 22.11.1995 № 171-Ф3 [ред. от 08.06.2020] // Собр. законодательства Рос. Федерации. - 1995. - № 48. - Ст. 4553.

6. О некоторых вопросах, возникающих у судов при применении Кодекса Российской Федерации об административных правонарушениях: Постановление Пленума Верховного Суда РФ от 24.03.2005 № 5 [ред. от 19.12.2013] // Бюллетень Верховного Суда РФ. - 2005. - № 6.

7. Додонов, В. Н. Сравнительное уголовное право. Общая часть / под общ. ред. С. П. Щербы. - М.: Юрлитинформ, 2009. - С. 317.

8. Левин, А.Н. Проблемы конфискации орудия совершения или предмета административного правонарушения /А.Н. Левин // Академическая публицистика. - 2019. - № 9. - С. 45-49.

9. Максимов, И.В. административные наказания в системе мер административного принуждения: дис... канд.юр.наук: 12.00 .14 /И.В. Максимов. - Саратов, 2004. - С. 340-341.

10. Официальный сайт Федеральной службы по регулированию алкогольного рынка. Результаты проверок за 2019 год [электронный ресурс] - Режим доступа: http://fsrar.ru/activities/rezultatyproverok/rezultaty_proverok_za_2019_god (дата обращения: 23.06.2020).

11. Чувилов, А.А. Административная природа конфискации орудия совершения или предмета административного правонарушения как вида административного наказания /А.А. Чувилов // Вестник науки. - 2019. - Т. 3. - № 5 (14). - С. 324-332. 


\section{РАЗДЕЛ IV. МЕЖДУНАРОДНОЕ ПРАВО}

\section{Чертова Н.А., Жура С.Е., Тетерин А.В. \\ Правовые аспекты регулирования международного научно-технического сотрудничества в сфере комплексного изучения Арктики}

Северный (Арктический) федеральный университет имени М. В. Ломоносова (Россия, Архангельск)

doi:10.18411/spc-20-08-2020-08

idsp: sciencepublic-20-08-2020-08

Исследование выполнено при финансовой поддержке Российского фонда фундаментальных исследований (РФФИ) в рамках научного проекта № 18-2915055 «Разработка правовой модели международного научно-технического сотрудничества в сфере комплексного изучения Арктики»

В научных работах проблемы регламентации международного научнотехнического сотрудничества в сфере комплексного изучения Арктики неоднократно рассматривались в контексте процессов глобализации и интеграции. В сложившейся ситуации международное научно-техническое сотрудничество призвано способствовать развитию российской науки, реэкспорту научных знаний, построению системы устойчивого взаимодействия науки, образования и бизнеса. Международное сотрудничество в области науки и технологий рассматривается как средство интеграции в мировое научное пространство, инструмент внешней политики Российской Федерации.

Анализ правовых аспектов регулирования международного научнотехнического сотрудничества в сфере комплексного изучения Арктики позволяет говорить о формировании договорных основ научно-технического сотрудничества, при этом большая часть соглашений о научно-техническом сотрудничестве в Арктике подчеркивают тесную связь научно-технической и экономической сфер взаимодействия, необходимость государственного стимулирования прямых научнотехнических связей, коммерциализации результатов исследований. Исследование авторов в данном направлении подтвердило перспективность дальнейшего «достраивания» модели научно-технического сотрудничества России с арктическими государствами в двухстороннем формате. Представляется необходимым включить в Стратегию развития Арктической зоны Российской Федерации до 2035 года раздел, посвященный международному научно-техническому сотрудничеству. При этом важно предусмотреть не только формы, принципы, направления, но и, с учетом зарубежного опыта, определить перспективы развития многостороннего и двухстороннего научнотехнического сотрудничества в Арктике с конкретными государствами.

Можно сделать вывод, что формирующаяся в течение последнего десятилетия российская правовая модель регулирования международного научно-технического сотрудничества в сфере комплексного изучения Арктики нуждается в существенной корректировке:

1. Деятельность в рамках международного научно-технического сотрудничества должна быть системной и долговременной, приводить к созданию новых научных и направлений и школ. Созданные механизмы сотрудничества (например, предоставление мегагрантов) с учётом непростой финансовой и социально-экономической ситуации должны предполагать коммерциализацию результатов исследований.

2. Практика создания и развития инновационных научно-технологических центров свидетельствует о необходимости: 
a) предварительной оценки рисков функционирования центра и рисков международного научно-технического сотрудничества (в том числе определения экономической обоснованности расходов);

б) чёткой регламентации результатов научно-технического сотрудничества, в том числе установления плановых целевых показателей и механизмов контроля за их достижением, определение показателей коммерциализации исследований;

в) учёта как положительного, так и негативного опыта создания и функционирования инновационных научно-технологических центров в

3. В актах стратегического планирования необходимо определить пространственные параметры взаимодействия научно-образовательных центров (в том числе НОЦ мирового уровня), а также отразить роль научно образовательных центров в Стратегиях социальноэкономического развития соответствующих субъектов Российской Федерации, включив положения о коммерциализации результатов исследований.

4. Необходимо сформировать и реализовать региональную программы грантовой поддержки научных исследований и академической мобильности в арктическом макрорегионе. В стратегиях социальноэкономического развития субъектов Арктической зоны, нормативных актах, регламентирующих реализацию научно-технической политики, следует отразить приоритетную для региона тематику и механизмы поддержки научных исследований. Кроме того, следует заимствовать положительный зарубежный опыт информационного обеспечения и поддержки международного научного сотрудничества.

5. Большая часть соглашений о научно-техническом сотрудничестве в Арктике подчеркивают тесную связь научно-технической и экономической сфер взаимодействия, необходимость государственного стимулирования прямых научно-технических связей, коммерциализации результатов исследований. Исследование подтвердило перспективность дальнейшего «достраивания» модели научно-технического сотрудничества России с арктическими государствами в двухстороннем формате. Представляется необходимым включить в Стратегию развития Арктической зоны Российской Федерации до 2035 года раздел, посвященный международному научно-техническому сотрудничеству. При этом важно предусмотреть не только формы, принципы, направления, но и, с учетом зарубежного опыта, определить перспективы развития многостороннего и двухстороннего научнотехнического сотрудничества в Арктике с конкретными государствами.

$$
* * *
$$

1. Указ Президента РФ от 05 марта 2020 г. № 164 «Об Основах государственной политики Российской Федерации в Арктике на период до 2035 года» // Собрание законодательства Российской Федерации. 2020. № 10. ст. 1317.

2. Указ Президента РФ от 26 февраля 2019 г. № 78 «О совершенствовании государственного управления в сфере развития Арктической зоны Российской Федерации» // Собрание законодательства Российской Федерации. 2019. № 9. Ст. 824.

3. Концепция международного научно-технического сотрудничества. Одобрена решением Правительства Российской Федерации от 8 февраля 2019 г. № ТГ-П8-952. [Электронный ресурс]. Режим доступа: https://france.mid.ru/upload/iblock/7f8/7f8aadb5de45b3a58103046d70eabef2.pdf (дата обращения: 16.05.2020).

4. Постановление Правительства РФ от 9 апреля 2010 г. № 220 «О мерах по привлечению ведущих ученых в российские образовательные организации высшего образования, научные учреждения и государственные научные центры Российской Федерации»// Собрании законодательства Российской Федерации. 2010. № 16. Ст. 1907 


\title{
РАЗДЕЛ У. УГОЛОВНОЕ ПРАВО
}

\author{
Агафонов B.B. \\ Анализ положений соборного уложения 1649 года о правомерном причинении \\ вреда при задержании лица, совершившего преступление
}

Нижегородская академия МВД России

(Россия, Нижний Новгород)

doi:10.18411/spc-20-08-2020-09

idsp: sciencepublic-20-08-2020-09

\section{Аннотация}

Статья посвящена зарождению и развития в российском праве нормы о правомерном причинении вреда при задержании лица, совершившего преступление. Автор на примере Соборного Уложения 1649 года провел исторический анализ развития правомерного причинения вреда при задержании лица, совершившего преступление. Выявлены положительные стороны и недостатки регламентации указанной нормы в Соборном Уложении 1649 года.

Ключевые слова: причинение вреда при задержании лица, совершившего преступление; Соборное Уложение 1649 года; необходимая оборона; превышение пределов причинения вреда.

\section{Abstract}

The article is devoted to the study of the origin and development of the law on lawful harm in Russian law when detaining a person who committed a crime. The author, using the example of the Cathedral Code of 1649, made a historical analysis of the development of lawful harm during the detention of a person who committed a crime. The positive aspects and shortcomings of the regulation of this norm in the Cathedral Code of 1649 are revealed.

Keywords: harm during detention of the person who committed the crime; Cathedral Code of 1649; necessary protection; exceeding the limits of harm with the necessary protection and detention of the person who committed the crime.

Научный и практический интерес представляют правовая природа и генезис нормы о правомерном причинении вреда при задержании лица, совершившего преступление.

Изучение зарождения и развития нормы о правомерном причинении вреда при задержании лица, совершившего преступление, необходимо для обнаружения положительного опыта и ошибок в законодательном регулировании рассматриваемого обстоятельства, исключающего преступность деяния, с учетом социальноэкономической и политической обстановки в России, в практике применения данной нормы, для установления ориентиров ее модернизации.

Анализ указанной нормы, закрепленной в Уложении царя Алексея Михайловича 1649 г. (позже названного Соборным Уложением), позволяет приблизиться к этим ориентирам.

Возможность причинения вреда при задержании лица, совершившего преступление, использовалась с древнейших времен: первые упоминания о своеобразной таковой возможности - в договоре князя Олега с греками 6420 г. от сотворения мира (911 г. от Рождества Христова), в договоре князя Игоря с греками 6453 г. от сотворения мира (944 г. от Рождества Христова) [1]. Условия правомерности и пределы допустимости причинения вреда при задержании лица, совершившего преступление, изменялись в процессе развития правовой системы государства.

Возможность причинения вреда при задержании лица, совершившего преступление, как самостоятельное обстоятельство, исключающее преступность 
деяния, и отдельная норма права появилась в российском законодательстве позднее. В России XVII века такое причинение вреда рассматривалось по правилам необходимой обороны.

В первой половине XVII в России обострились классовые и сословные противоречия, усилилось стремление царской власти подвергнуть правовой регламентации все стороны общественной жизни. Восстание 1648 г. подтолкнуло дворянство 10 июня 1648 г. принять «челобитную» царю. В послании от лица всенародного множества московского государства излагалось требование созвать Земский собор для принятия уложенной книги с целью создания единого законодательства. В результате работы Земского собора появился первый систематизированный в истории России закон -Уложение царя Алексея Михайловича (Соборное уложение) 1649 г., пройден новый этап в развитии юридической техники.

Г.С. Фельдштейн считал, что необходимая оборона получила законодательную формулировку именно в этом Уложении. По его утверждению, необходимая оборона, как самостоятельный институт, санкционировался обычаями и древнейшими законодательными памятниками только в связи с самоуправством. [3]

Такую же точку зрения выражал М.И. Якубович. По его мнению, Соборное Уложение 1649 г. можно назвать в полном смысле слова Уголовным кодексом, ибо в нем весьма обстоятельно рассматривались вопросы преступления и наказания. [4]

В названном нормативном правовом акте расширен институт обстоятельств, исключающих преступность деяния. В ст. 200 и ст. 201 гл. $\mathrm{X}$ «О суде» закреплено следующее: « А будет тот, к кому они таким умышлением приедут, бороняся от себя, и дом свой обороняя, кого из них убьет до смерти и привезет тех побитых к судья, и сыщется про то допряма, что он то убийство учинил по неволе, от себя обороняяся, и ему вину не ставить...» [5]

Иными словами, в данных статьях указывалось, что оборона разрешается как для самозащиты, так и для защиты третьих лиц, разрешалось защищать неприкосновенность жилища и имущества не только при поимки вора на месте, но и при задержании злочинца, оказывающего сопротивление.

В гл. XXI «О разбойных и татийных делах» особого внимания заслуживают ст.8, 88, 89, в которых регламентируется причинение вреда при задержании лица, совершившего преступление. В ст. 8 впервые закреплено поощрение доставления преступника в помещение Губного старосты для разрешения вопроса о передачи суду. Статья 88 содержала положение о том, что предоставлялось право потерпевшему (у кого в доме произошла кража) убить вора на месте преступления или при погоне в случае сопротивления. Впервые определялись основания и условия причинения вреда при задержании лица, совершившего преступление; лишать жизни и причинять вред запрещалось, если вор не оказывал сопротивления. В ст.89 закреплено правило, согласно которому, если задерживающий лишил жизни преступника, который оказывал сопротивление или пытался скрыться при задержании, то последний освобождался от наказания, однако для того чтобы « от убийства освободиться», лицо задерживающие преступника должно было соблюсти два обязательных условия. [5]

Первое условие: задерживающий должен убитого или раненого задерживаемого лица вместе с поличным «явить окольным людям вскоре». Этого не требовалось, если задержание происходило не одним задерживающим лицом.

Второе условие: задерживаемое лицо полагалось «привести в приказ записать». Если в погоне участвовали посторонние люди, они также должны были явиться в приказ для показаний. По всей видимости данные правила были необходимы для того, чтобы доказать правомерность причинения вреда задерживаемому лицу и доказать сам факт нападения.

Нельзя оставить без внимания ст.16, 21 и 22 гл. XXII «За какие вины кому чинити смертная казнь, и за какие вины смертию не казнити, а чинити наказание». В данной главе регламентируется необходимая оборона. Впервые законодательно 
закрепляется не только право на самооборону, но и право на защиту интересов третьих лиц, вводится обязанность слуг защищать своих господ под страхом наказания.

Статьи 21 и 22 гл. XXII Соборного Уложения регламентировали ответственность слуг при превышении пределов необходимой обороны. За убийство преступника спрашивалось не со слуги, а с лица, которому он служит, а если же убийство учинено без ведома господина, слуга подлежал смертной казни.

Подводя итог, следует отметить, что Соборное Уложение 1649 г. - первый кодифицированный нормативно-правовой акт, который закрепил необходимую оборону как обстоятельство, исключающее преступность деяния, регламентировал порядок и условия правомерности причинения вреда при задержании лица, совершившего преступление, в отличие от предыдущих законодательных актов. Поощрялось доставление вора или разбойника в губную избу, законодательно ограничен самосуд над лицами, совершившими преступления. Таким образом, законодательно оформляется цель задержания - доставление в органы власти преступника для дальнейшего его наказания. Причинение вреда при задержании лица, совершившего преступление, регламентировалось по правилам необходимой обороны, однако возможность причинения такого вреда была значительно расширена по сравнению с таковой, закрепленной в предыдущих нормативно-правовых актах.

Итак, Соборное уложение 1649 г., по сравнению с предшествующими нормативно-правовыми актами, имело следующие положительные стороны.

1. Более детально изложены положения о причинении вреда при задержании лица, совершившего преступление.

2. Впервые законодательно поощрялось доставление преступника в государственные органы.

3. Законодательно ограничивались случаи самосуда и расправы над преступником.

4. Впервые целью задержания виновного объявлялось доставление его в органы власти для решения вопроса о назначении ему наказания.

5. Определены основания и условия причинения вреда при задержании лица, совершившего преступление.

6. Регламентирована помощь третьим лицам, определена ответственность за превышение пределов оказанной помощи.

При всех положительных сторонах Соборного Уложения 1649 г. существовал ряд недостатков, а именно: в законе не говорилось о соразмерности защиты характеру и степени общественной опасности посягательства, о превышении пределов причинения вреда при необходимой обороне и задержании лица, совершившего преступление. По смыслу закона, правомерным признавалось как причинение вреда здоровью, так и убийство злочинца.

Соборное Уложение 1649 г. явилось новым этапом в развитии юридической техники и первым в истории России систематизированным законом. [5]

$$
* * *
$$

1. Сверчков В.В. Ведение в уголовное право. Уголовный закон: учебное пособие для бакалавриата, специалитета и магистратуры. М.: Издательство Юрайт, 2019. С. 201; Повесть временных лет по Лаврентьевской летописи 1377 г. (подготовка текста, перевод, статьи и комментарии Д.С. Лихачева; под ред. В.П. Адриановой-Перетц. 3-е издание. СПб.: Наука, 2007. С. 666.

2. Тихомиров М. Н. Соборное уложение и городские восстания середины XVII в. // Классовая борьба в России XVII в. М.: Наука, 1969. С. 446

3. Фельдштейн Г.С. О необходимой обороне и ее отношении к так называемому «правомерному самоуправству». С.53 // Журнал Министерства Юстиции. 1899. № 5. С. 458

4. Якубович М.И. Вопросы теории и практики необходимой обороны. М. 1961. С.223.

5. Российское законодательство X-XX веков: в 9 т. Т.3: Акты Земских соборов / под общ. ред. О.И. Чистякова. М. Юрид. лит., 1985. С. 512. 


\section{Dля заметок}




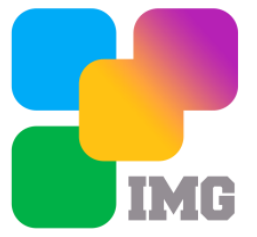

Научное издание

\section{Научный диалог: Юриспруденция}

Сборник научных трудов по материалам XXIII международной научно-практической конференции 20 августа 2020 г.

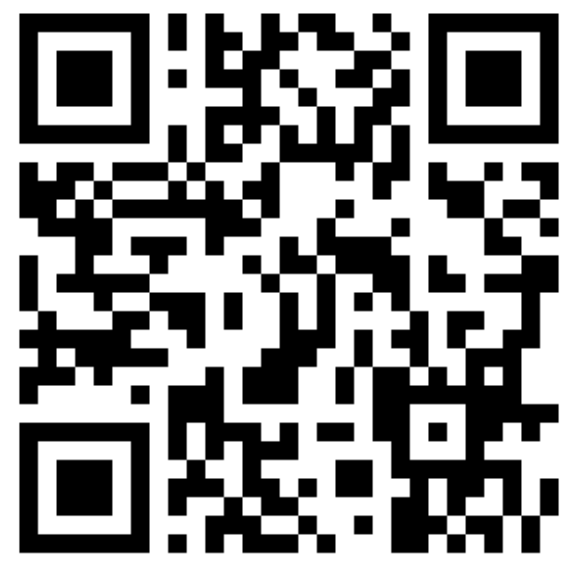

SPLN 001-000001-0686-JP

Подписано в печать 21.08.2020. Тираж 400 экз. Формат.60х84 1/16. Объем уч.-изд. л. 1,38 Бумага офсетная. Печать оперативная.

Отпечатано в типографии НИЦ «Л-Журнал»

Главный редактор: Иванов Владислав Вячеславович 